\title{
MOTIVSTUDIER
}

\section{Kontinuitet og fornyelse i ornamentale hybridformer fra antikken til ca. 1600}

Forfølgelsen af motivers udformning og udvikling igennem århundreder og fra sted til sted har, sammen med påvisning af inspirationskilder i form eller indhold, været en udbredt praksis i det 20. århundredes kunsthistorie. Men metoden har på trods af sin udbredelse ikke altid været fulgt af refleksioner over dens legitimitet. I de senere årtier har andre analytiske greb taget over, betinget af humanisters tiltagende specialisering inden for begrænsede områder og perioder, en dertil hørende ulyst ved generaliseringer, og, ikke mindst, en modvilje mod overhovedet at beskæftige sig med "udvikling", med alt hvad begrebet indebærer af darwinistiske og teleologiske associationer og hierarkiske absolutismer. Men selvom motivstudierne kan rumme problemer og implicitte dagsordner, man kan forholde sig kritisk til, giver de imidlertid også overblik, som detailstudier og mikrohistoriske undersøgelser ikke kan tilbyde.

Motivstudierne kan som greb have modsatrettede mål, nemlig at betone enten ligheder eller forskelle, enten sammenhænge eller transformationer. På den ene side kan de dokumentere forbindelser over tid og sted. Derved kan de justere en historieforståelse baseret på ideer om opdagelser og opfindsomhed: Ved at fremhæve kontinuitet frem for fornyelse kan de bidrage til et opgør med den meget udbredte og ofte ureflekterede anakro- 
nistiske tilbageførelse af modernitetens fremskridts- og originalitetsbegreb på fortiden, f.eks. middelalderens og renæssancens billedverden. På den anden side kan motivstudierne klargøre fornyelser fra en periode eller generation til den næste. Forudsat at man overhovedet anerkender, at der er forskel på kunstneriske udtryk i forskellige historiske perioder og kulturer, er motivstudierne en mulighed for at kortlægge, hvor og hvordan disse forskelle manifesterer sig, og dermed også at reflektere over, hvorfor forandringerne finder sted.

I artiklens første afsnit vil jeg skitsere den historiografiske situation omkring motivstudier i kunsthistorien for dermed at bidrage til en klargøring af metodens implicitte ideologier og potentiale. Derefter, vil jeg i artiklens to efterfølgende afsnit forsøge et dobbeltgreb med en bestemt motivkreds som eksempel, nemlig ornamentale hybridformer (planter, mennesker, dyr i forskellige kombinationer), hovedsageligt svarende til dét, som $\mathrm{i}$ arkæologisk terminologi betegnes peopled scrolls. Jeg vil argumentere imod en stadig udbredt opfattelse af renæssancen som en genoplivning af antikken, idet jeg forfølger traditionen af ornamentalt rankeværk fra antikken frem til 1500-tallet. Det vil sige, at jeg fremhæver kontinuitet med middelalderen. Og jeg vil samtidig argumentere for, at 1500-tallet alligevel repræsenterer et nybrud. Det er blot ikke en genopdagelse af antikken, der er omdrejningspunktet for dette. En analyse af tradition og fornyelse kan, vil jeg mene, klargøre noget af det særlige ikke kun ved 1500-tallets ornamentale udtryk, men ved periodens visuelle kultur i det hele taget. En forklaring på dette kan findes i det syn på kunst og natur, som gør sig gældende i 1500-tallet i spændingsfeltet mellem et antik-middelalderligt og et moderne verdensbillede.

\section{OPTAKT: OM MOTIVSTUDIER I KUNSTHISTORIENS HISTORIE}

Da Ernst Robert Curtius i 1953 skulle sammenfatte sit allerede legendariske projekt i forordet til den første engelske udgave af Europäische Literatur und Lateinisches Mittelalter, var det ham magtpåliggende at betone de overordnede kulturpolitiske implikationer i undersøgelserne af litterære motivers vandringer fra den romerske oldtid og videre igennem den latinsksprogede middelalder. For Curtius var påvisningen af sammenhænge mellem for- 


\section{MARIA FABRICIUS HANSEN MOTIVSTUDIER}

skellige folkeslag og fra generation til generation dét, han som humanist kunne bidrage med i bestræbelserne på at nå frem til en fredelig europæisk sameksistens efter to verdenskrige på mindre end et halvt århundrede. De bemærkelsesværdigt omfattende og vedvarende forbindelser, han kunne kortlægge ved hjælp af sine litterære motivstudier, var for ham et åbenlyst argument for de europæiske nabolandes intellektuelle slægtskab. Et argument for, at vi i det relativt nye fænomen, som nutidens Europa med dets landegrænser og nationalstater var, havde mere tilfælles, end vi måske umiddelbart gjorde os klart. Projektet synes desværre ikke mindre aktuelt i dag, end det var i dønningerne efter 2. Verdenskrig.

Den optagethed af tematiske og stilistiske motivers vandringer over tid og sted, som Curtius' kortlægning af litterære topoi var baseret på, gik igen hos mange andre af hans samtidige (Focillon; Baltrusaitis; Gombrich). Den repræsenterer en fascination af sammenhænge og ligheder, som imidlertid er sjælden i dag svarende til fordrivelsen af - eller befrielsen fra - de store fortællinger. Som et barn af moderniteten med dens fremskridts- og originalitetsdyrkelse har kunsthistorien dyrket opdagelsen og fornyelsen som kunstneriske fænomener, med en dertilhørende fremhævelse af de enestående kunstnerindivider, hvis opfindsomhed, har man ment, bragte den kunstneriske udvikling videre. Det forekommer i dag åbenlyst, at man derved har tilbageskrevet et moderne kunstbegreb og et moderne kunstnerideal på en historisk fortid, hvor der i realiteten ikke var tale om enestående kunstnere, der frit udtænkte hidtil usete værker, men snarere om en praksis af mesterlære, indarbejdelse af billedtraditioner ved kopiering og værkproduktion i form af teamwork i ofte omfattende værkstedsamarbejder. Der har tilmed i kunsthistorien ligget en forkærlighed for bestemte historiske perioder, hvor den græsk-romerske antik og den (italienske) renæssance har haft en høj status. Her har kunstneren og kunstteoretikeren Giorgio Vasaris fremstilling fra midten af 1500-tallet af den italienske kunsts historie, med en forherligelse af florentinsk renæssancekunst og af antikgenoplivning som kunstnerisk praksis, og J.J. Winckelmanns fremstilling af den antikke kunsts historie fra 1700-tallet, haft en særlig gennemslagskraft.

Denne forkærlighed for den italienske renæssance og for antikken har resulteret i et udbredt kunsthistorisk forehavende: at påvise "antikgenoplivninger" i renæssancen. Altså at argumentere for en sammenhæng 
112 KULTUR \& KLASSE * $123 * 2017$

TOPOLOGI

mellem renæssancens opfindsomhed og enestående fornyelse i forhold til middelalderen, og at hævde at denne fornyelse kan forstås som resultatet af en bevidst genoplivning og imitation af antikken. Selve påvisningen af et antikt forbillede har været så selvindlysende legitimt som forehavende i kunsthistoriske analyser, at man end ikke har spurgt til, hvorfor den såkaldte genopdagelse eller genoplivelse af antikken var så vigtig (Weiss; Dacos). Det 20. århundredes måske mest læste kunsthistoriker, Erwin Panofskys indflydelsesrige Renaissance and Renascences (1960) byggede eksempelvis på den stiltiende præmis, at selve forståelsen af renæssancen som periode måtte defineres ud fra det forhold, man havde til antikken.

Med den nye interesse i de senere årtier for at nedtone fornyelses- og opdagelsesretorikken er der imidlertid fulgt en genbetoning af kontinuitet og sammenhænge på tværs af kunsthistoriske periodiseringskonstruktioner. Den britiske kunsthistoriker Jas Elsner har opdyrket et helt nyt felt ved at forene antikkens kunst, som før var arkæologernes og antikhistorikernes speciale, med middelalderens, som var kunsthistorikernes og kirkehistorikernes domæne, idet kristendommen, som blev lovliggjort og indført som statsreligion i løbet af 300-400-tallet, fungerede som skillelinje (Elsner, Art and the Roman Viewer og Imperial Rome and Christian Triumph). Elsner har nedtonet betydningen af kristendommens indførelse og i stedet udarbejdet fremstillinger, der bygger bro over den gængse periodeadskillelse. Ved at lade fremstillingen begynde i romersk kejsertid og strække sig ind i den tidlige kristne middelalder har Elsner tydeliggjort sammenhængene og kontinuiteten over tid. Desuden har en række kunsthistorikere, ikke mindst Georges Didi-Huberman i Frankrig og Alexander Nagel og Christopher S. Wood i USA, lagt afstand til de store navne i kunsthistorien fra midten af det 20. århundrede (typisk Panofsky), for i stedet at gribe tilbage til deres fælles læremester, Aby Warburg. For Warburg udgjorde netop motivforfølgelser og kontinuitetsiagttagelser den grundlæggende metode (Didi-Huberman, Atlas, "Nachleben" og "Renaissance et impureté du temps"; Johnson). Også østrigeren Aloïs Riegl, der skrev en række vigtige værker i årene omkring 1900, er taget op med fornyet interesse i de seneste årtiers kunsthistorie, helt konkret ved at en række af hans bøger er kommet i engelsk oversættelse. Riegls Stilfragen: Grundlegungen zu einer Geschichte der Ornamentik (Berlin 1893, oversat til engelsk i 1992), er et velargumenteret forsvar for 


\section{MARIA FABRICIUS HANSEN MOTIVSTUDIER}

topologiske studier i form af kortlægning af ornamenters udvikling og vandring over tid. De plante- eller rankeornamenter, Riegl koncentrerede sig om, er kun et eksempel af i princippet uendeligt mange på motiver, som videreformidledes rundt i Romerriget. Der var visse lokale justeringer, men først og fremmest en slående kontinuitet.

Parallelt hermed formulerede Riegls og Warburgs samtidige, schweizeren Heinrich Wölfflin i Kunstgeschichtliche Grundbegriffe (1915) en formalistisk analysemodel, hvor han påpegede modsatte stilistiske grundgreb i to arketypiske perioder, renæssancen (som han kaldte den "klassiske kunst", det vil sige kunsten omkring år 1500) og barokken (kunsten i 1600-tallet). For Wölfflin drejede det sig om at uddestillere nogle essentielle egenskaber i kunsten, i første omgang i de to specifikke perioder, men på længere sigt også tænkt som almene modsætningslove som styrede kunsten dialektisk igennem århundrederne, i en form for bevægelse og modbevægelse mellem det klassiske og det barokke som transepokale fænomener.

Men som Wölfflin samtidig bemærkede, og som Riegl eller Warburg næppe har været uenige i, er det en fejl at tro, "at alt skulle være muligt til alle tider" (Wölfflin, Klassische Kunst 293). Selv i disse formative år i den kunsthistoriske faglighed, hvor lovmæssigheder og strategier for kunsthistorisk udvikling blev formuleret, var der en anerkendelse af, at nybrud også gør sig gældende i kunstens historie. At der har været visse mulighedsbetingelser i en given tid, der både har formet den visuelle kultur, og som den visuelle kultur omvendt også selv har medvirket til at give form.

Der tegner sig således et komplekst felt af historiske baggrunde og metoder i forhold til studiet af tradition og fornyelse i kunstens historie. Men selvom en vis søgen efter inspirations- og påvirkningskilder har været fælles for mange af de kunsthistoriske faderfigurer, kan man skelne mellem en betoning af prototyper og af topoi. På den ene side har vi en idé om f.eks. renæssancen som en genoplivning af antikke prototyper. Ideen om prototypen er baseret på en forestilling om, at der i renæssancen finder en fuldbyrdelse sted af en form, som antikken rummede kim til. På den anden side har vi en idé om topoi, om ikonografiske og stilistiske traditioner, som videreføres kontinuerligt.

Fascinationen i iagttagelsen af billedformers videreførelse, altså af styrken i ikonografiske traditioner, ligger i det slående, at man ser verden 
114 KULTUR \& KLASSE * $123 * 2017$

TOPOLOGI

gennem billeder; man har blik for motiver, som man allerede i forvejen kender som billeder. Men på den anden side ligger der også en fascination i anerkendelsen af, at alt ikke altid er det samme, at der faktisk sker ændringer og fornyelser og "opfindelser" igennem tiden, som får udviklingsforløbet til at forskyde sig i nye retninger og betydninger. Altså en fascination af både videreførelse/kontinuitet og af transformation.

I det følgende vil jeg forsøge at genoptage det topologiske projekt, idet jeg vil forfølge menneske-, dyre- og plantehybrider fra antikken og frem til renæssancen ud fra iagttagelser af sammenhænge og ligheder. 1400-1500-tallets hybride ornamenter ligger i umiddelbar forlængelse af senmiddelalderens og ville ikke kunne forstås og forklares, uden at denne tradition tænkes ind i sammenhængen. Med den underliggende idé om, at der er tale om kontinuerlige videreførelser af motivtraditioner, følger også en modificering af de udbredte påstande om renæssancen som en "genopdagelse" eller "genoplivning" af antikken. Denne gængse forståelse af renæssancen bygger ganske vist på periodens egne påstande og egen selvforståelse, men den undlader som oftest at forholde sig kritisk til, hvad det så var for et antikbegreb, man opererede med. For hvad mente de egentlig i renæssancen, når de hævdede, at de arbejdede "all'antica"?

På den anden side mener jeg, at studiet af den motiviske udvikling også kan bidrage til at karakterisere det helt særlige ved 1400-1500-tallets visuelle kultur. Her er det således snarere forskellen end ligheden med det antikke udgangspunkt, som er i fokus, og snarere fornyelsen end kontinuiteten. Her er det ikke videreførelsen af den visuelle tradition igennem middelalderen, men transformationen af den, som bliver afgørende for at forstå karakteren af 1500-tallets kunst. Så på trods af et ønske om at se sammenhænge og betone ligheder, bygger artiklen på den wölfflinske tankegang: en del af det, der gør sig gældende i 1500-tallets visuelle kultur var ikke muligt tidligere. Artiklen her repræsenterer således en anerkendelse af, at 1500-tallets kunst adskiller sig fra den forudgående. Blot er det ikke antikinspirationen, der er den primære forklaring på dette.

Ved den ofte ukritiske sidestilling af den antikke billedkunst med renæssancens mangler der en sammenligning af de to og en karakteristik af, hvad forskellen så er. At imitere antikken er en praksis, som vi antager, at man som kunstner påtager sig, hvis man har et ideal; men det er ikke 


\section{MARIA FABRICIUS HANSEN MOTIVSTUDIER}

sikkert, at man dengang forholdt sig til idealet på dén måde, især hvis vi medregner, at begreberne kopi og original er moderne og var fremmede for tankegangen omkring 1500. For når man ikke er i stand til at producere tro kopier, giver det heller ikke mening at tænke i ægte originaler. Først med bogtrykkerkunstens og den grafiske billedreproduktions gennembrud (i form af træsnit og kobberstik) i anden halvdel af 1400-tallet begyndte den gentagelse og sammenligning, som er forudsætningen for begreberne kopi og originalitet, at kunne finde sted.

Det materiale, vi skal se på i det følgende, er ornamentalt rankeværk med figurmotiver indarbejdet, enten menneskefigurer eller dyr. Disse kombinationer ses tidligst i græsk senklassisk og hellenistisk kunst og bliver et almindeligt dekorativt figurmotiv i romersk kunst: phytomorfe figurer (mennesker med hale- eller skørtelignende underkroppe af blade, ansigter kombineret med bladværk, dyr, der udspringer af akantusranke) eller kombinationer af menneske og dyr (kentaurer, havfruer, satyrer, eroter eller sejrsfigurer med vinger). ${ }^{1}$

\section{BILLEDTRADITIONER OG MOTIVKONTINUITET}

Hvor enkeltstående plantemotiver såsom lotusblomster og palmetter var hyppigt anvendt i ægyptisk og assyriologisk oldtid, var koblingen af disse ornamenter med dynamiske rankemotiver et ornamentalt koncept, der først blev udviklet i antikkens Grækenland, fra omkring det 5. århundrede f.v.t. og frem (Toynbee \& Ward-Perkins 1-43; Riegl, Problems of Style). Den naturalisme, som grækerne og siden romerne tilstræbte i fremstillingen af menneskekroppen, var forbundet med eller betinget af en ny interesse for bevægelse. Naturalistiske rankemotiver, typisk akantus- eller vinrankelignende planter, er i det hele taget utænkelige uden en visuel kultur, der inkluderer en bevæget, rumligt veldefineret kropslighed. Og samtidig med udviklingen af rankemotivet som ornamental form, opstod også

1 Da det følgende kun kan være et hurtig rids af en omfattende, kompleks udvikling, må jeg henvise til den mere omfattende analyse af disse ornamentformer fra antikken til 1500-tallet i min kommende bog, The Art of Transformation: Grotesques in Sixteenth-Century Italy. Rom: Quasar Edizioni, under udgivelse. 
116 KULTUR \& KLASSE * $123 * 2017$

TOPOLOGI

koblinger af figurfremstillinger (mennesker eller dyr) og planter, endda i nogle tilfælde også som hybridformer: akantusranker, hvor figurer eller dyr kommer til syne eller vokser frem af blomsterknopperne, eller ansigter, der er indrammet af blade eller synes at gro frem ved rankeværkets fod (billede 1 og 2). Motiverne ses i alle teknikker og medier såsom marmorrelieffer, gulvmosaikker, keramik, metalarbejder, tekstil og freskomaleri. Disse kompositte figurer har rødder i antikkens naturreligiøse mytologi, ikke mindst repræsenteret ved ideerne om en Moder Jord-gudinde, en skabende, livsgenererende kraft, der er til stede i naturen (Ludwig Curtius 192-210; Schauenburg 198-221; Rupp 211-219). Ifølge denne tankegang var naturen potentielt billeddannende; figurer og former lå latent i naturens materialer og kunne opstå spontant (Aristoteles 2: 8, 199a, 10 ff; Plinius d. Æ. XXXVI, 125, XXXVII, 5; Janson; Wamberg vol. 2, 247-363). Men naturens billeddannelse kunne også udfoldes billedkunstnerisk gennem fremstillinger af hybridvæsner, hvis egentlige eksistens i den fysiske virkelighed var uvis. Både Vitruvius, i afhandlingen om bygningskunst, og Horats, i Ars Poetica (begge romere fra det 1. årh. f.v.t.), opponerede mod en kunstnerisk frihed, som havde brud på naturalisme som konsekvens (Vitruvius 91-92; Horats 450-451). Kunstens mulige overskridelse af det, naturen frembringer, og ikke mindst den kritiske indstilling til dette, blev et topos i de efterfølgende århundreders kunstteoretiske refleksioner (Bernard de Clairvaux 170; Pictor in Carmine 109; Cennini 26). Ikke desto mindre vedblev billedformen, både koblingen af figur og plante og koblingen af menneskeoverkrop og dyreunderkrop, at dukke frem i både middelalderens og renæssancens billedkunst. Rankeornamentikken levede et videre liv op igennem den oldkristne senantik og middelalderen, både i form af mosaikudsmykninger i apsider og kupler, som vedvarende er synlige (f.eks. i kirker i Rom), og i den udbredte genanvendelse af antikkens ornamentalt udsmykkede marmorelementer i nye sammenhænge (såkaldte spolier). Grundlæggende arbejdede de post-antikke generationer videre i forlængelse af værkstedstraditioner og nedarvede teknikker og ikonografiske traditioner (billede 2).

I logisk forlængelse af senantikkens og den tidlige middelalders stilisering og distance til naturalistisk bevægelighed, der gik hånd i hånd med kristendommens gennembrud (Brown), opstod ganske vist en isolering 
117 MARIA FABRICIUS HANSEN MOTIVSTUDIER

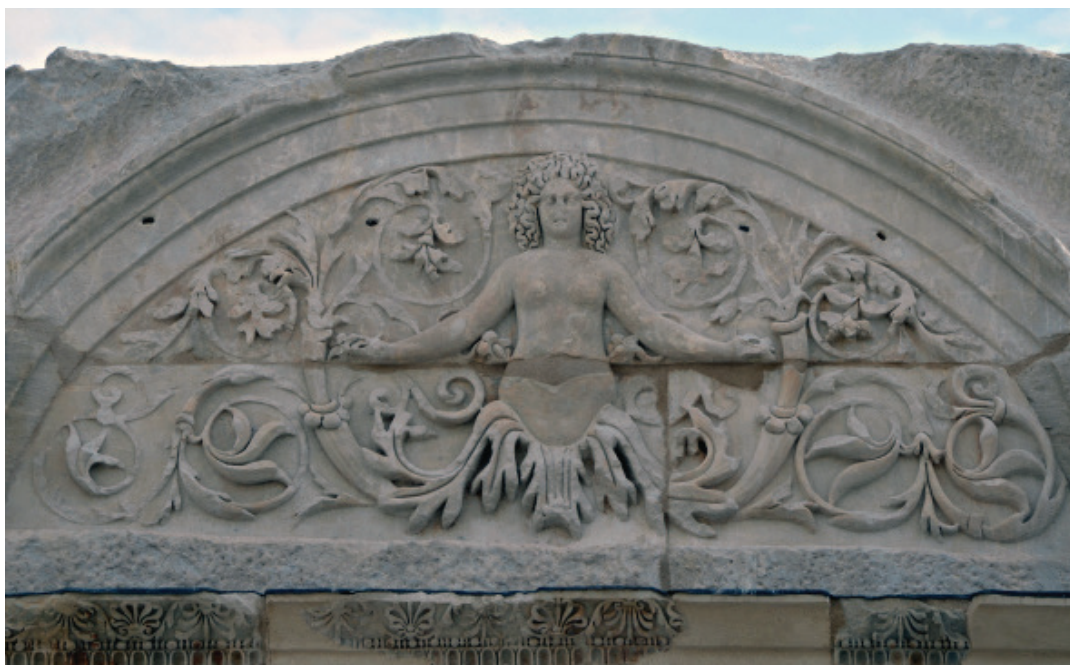

Fig. 1. Relieffra Hadrians tempel, Ephesus, 2. årh. Foto: ㄷJosé Luiz Bernardes Ribeiro, Wikimedia Commons

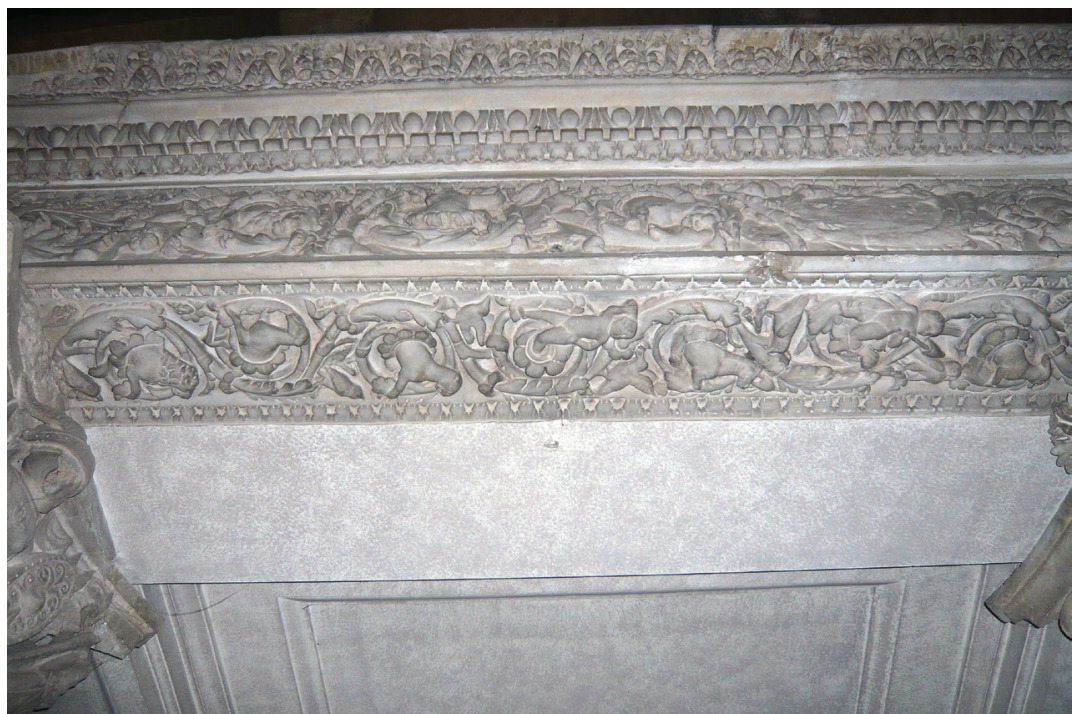

Fig. 2. Romersk marmorbjælke med relief med "peopled scroll"-motiv, det vil sige rankeværk med figurer og dyr. Genbrugt som overligger mellem søjler i den middelalderlige kirke San Lorenzo fuori le Mura (6. årh.), Rom. Foto: Maria Fabricius Hansen 
118 KULTUR \& KLASSE * $123 * 2017$

TOPOLOGI

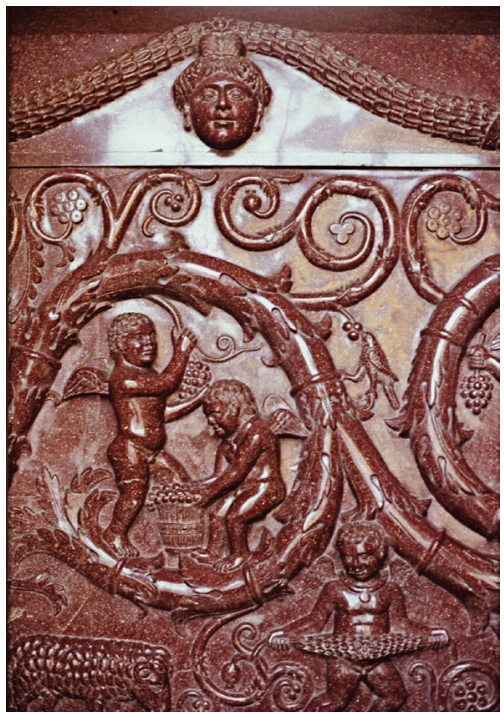

Fig. 3. Udsnit af porfyrsarkofag udført for kejser Konstantins familie, 4. årh., Vatikanmuseet. Foto: Maria Fabricius Hansen.

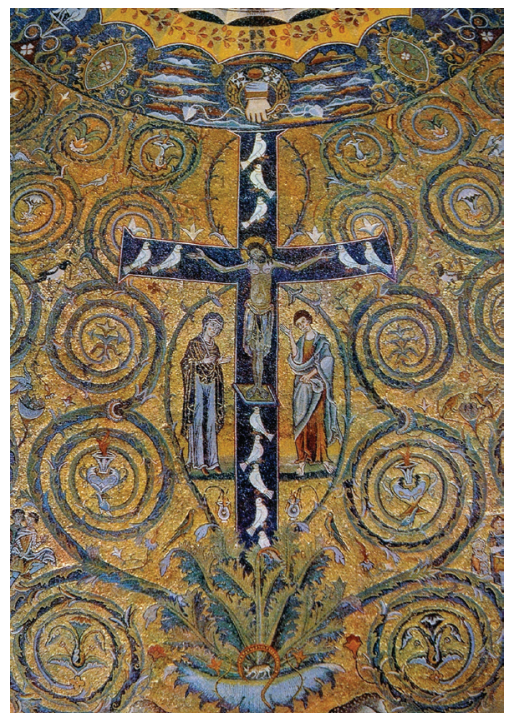

Fig. 4. Kors, der vokser frem af rankeværk. Detalje af mosaik fra San Clementes apsis, 12. årh., Rom. Foto: (C) Jastrow, Wikimedia Commons

af de enkelte figurelementer, der også bevirkede, at hybridformer opdeltes i veldefinerede enkeltkroppe: Ranker og menneskefigurer blev stadig anvendt som ornament, men som klart adskilte former (Ludwig Curtius 204-206; Riegl, Spätrömische Kunst-Industrie 389-412) (billede 3). Figurer blev kombineret med stiliserede akantus- eller vinranker, men snarere end at gro frem af selve plantens rod, blev figurerne fremstillet som placeret på eller over plantens udspring. I store mosaikudsmykninger som i San Clementes apsis (Rom, 1100-tallet), tog korset plads ved rankeværkets udspring som erstatning for oldtidens phytomorfe figurer (billede 4). I forlængelse af denne tradition er også det såkaldte Jesse rod-motiv, baseret på en gammeltestamentelig profeti (Esaias 11,1) om slægten, der førte frem til Kristus. Det visualiseredes fra 1100-tallet og frem som et vidt forgrenet træ med figurer indrammet af grenene eller halvfigurer, der sidder i eller udspringer af blomsterkalke. 


\section{MARIA FABRICIUS HANSEN MOTIVSTUDIER}

I denne periode opstår nye ornamentale koblinger af rankeværk og menneske- eller dyrefigurer i en hidtil uset udfoldelse af hybriditetsmotiver. Fra omkring 1100-1200-tallet (overalt i den vestlige verdens kulturelle centre) blev der arbejdet med opfindsomme figursammenstillinger. Håndskrifternes marginalier og kirker og klostres figurkapitæler og ornamentale rankeværk er markante eksempler på en praksis, der ikke kun gentog fortidens hybridformer, men også øgede den fantasifulde, groteske sammenstilling af motiver markant (billede 5). I forlængelse af Panofskys analyse af det perspektiviske rums udvikling og betydning kan man konstatere, at efterhånden som en ny rumlighed voksede frem omkring figurerne, voksede også deres bevægelighed (Panofsky, Perspektive). Dermed genopstod hybriditeten som motiv, efter den tidligere middelalders sparsomhed på sammensmeltninger af eksempelvis plante og menneske eller dyr. Nyt i forhold til antikkens hybrider var imidlertid en dimension af kontinuerlighed og sammenhæng i fremstillingen af figur og rum.

Denne rumlige og bevægelsesmæssige kontinuerlighed kom ikke kun til udtryk i fascinationen af hybrider, men også i formmæssige metamorfoser. Som Caroline Walker Bynum har iagttaget i Metamorphosis and Identity (2005), er det afgørende at skelne mellem hybriden og metamorfosen som to forskellige formmæssige (og indholdsmæssige) greb (Bynum 29-34). Antikkens billedkunst er rig på hybrider, men det er som oftest veldefinerede kropspartier, der er adderet op til nye, veldefinerede væsner. Højmiddelalderens billedkunst (fra 1100-1200-tallet og frem) udforsker imidlertid metamorfosen, som er de flydende, sømløse overgange fra en form til en anden, med fascinationen af foranderligheden eller selve forvandlingen som ny tematik (billede 6).

Hvorfor finder der i denne periode en forandring sted i retning af denne nye rumlige og bevægelsesmæssige kontinuerlighed i de billedelementer, som havde været til stede fra romernes pluralistiske kulturoversættelser (ved overtagelser eller tilegnelser ikke kun fra det græske område, men fra alle de områder, de erobrede) og frem igennem middelalderen?

Man kan med Walker Bynum som en af mange pege på oprindelsen af en række samfundsmæssige vilkår, der synes at fortsætte frem til det moderne. Walker Bynum fremhæver især de vilkår, der i sig rummer en forestilling om mulig forandring, nemlig korstog og pilgrimsfærd (Bynum 
120 KULTUR \& KLASSE * $123 * 2017$

TOPOLOGI

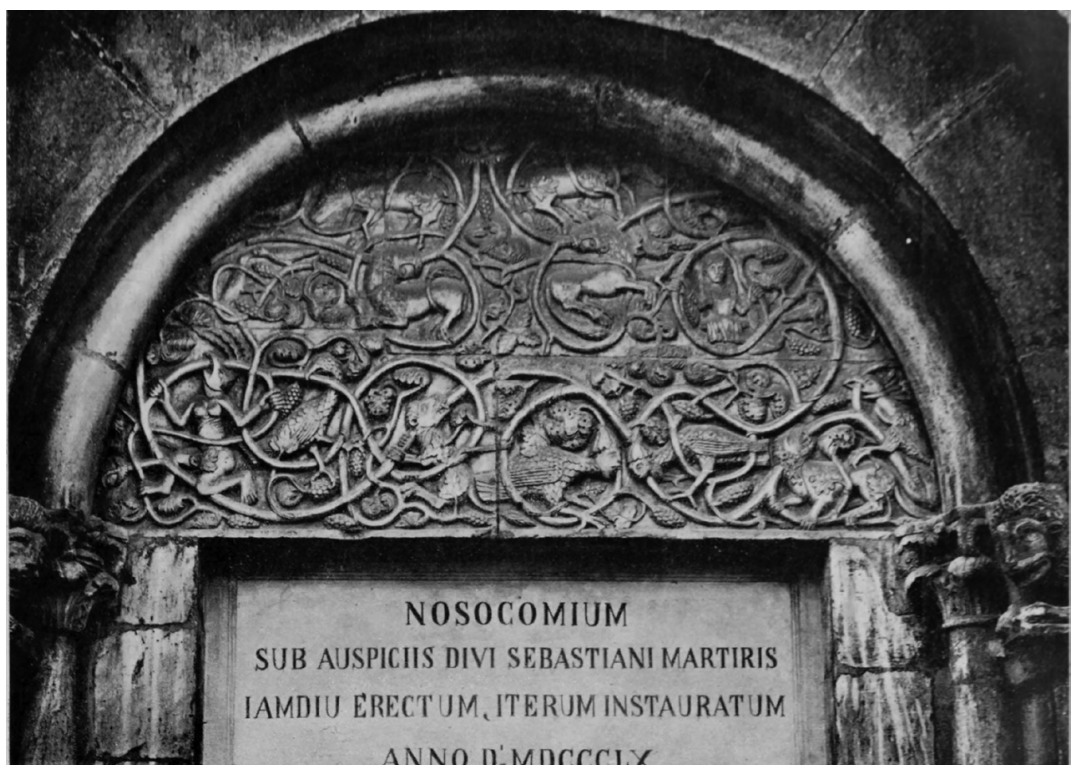

Fig. 5. Romansk kirkeportal med rankeværk og hybridvæsner. Capranica (Viterbo). Foto: (c) Roberto Piperno

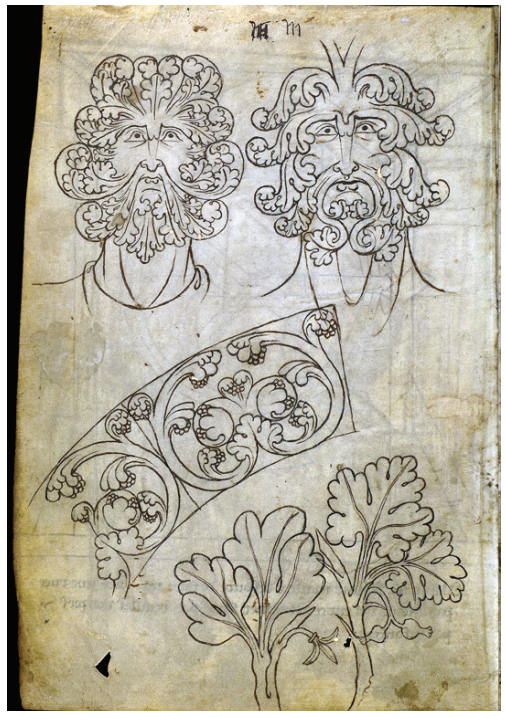

Fig. 6. Villard de Honnecourt. Villard de Honnecourt, skitsebog fra ca. 1230. MS. 19093 Franske samling, Bibliothèque Nationale, Paris. Foto: http://classes.bnf.fr/villard/feuillet/ feuille1/1011.htm 


\section{MARIA FABRICIUS HANSEN MOTIVSTUDIER}

21-26). Det var sociale strømninger, der voksede frem fra omkring årtusindskiftet, og som indebar, at man ved at bevæge sig, rejse, kunne forandre skæbnen i retning af frelse. Konfrontationerne og udvekslingerne med fremmede kulturer, ikke mindst den muslimske, førte på én gang til en øget bevidsthed om "den anden" og om egen, lokal identitet. Den generelle tendens i perioden til at arbejde i folkesprog (altså det lokale udtryk), også kunstnerisk og stilmæssigt, er blot et eksempel af mange på dette. Ikke mindst voksede der i kølvandet på 1000-1100-tallets klostre en bykultur frem, som blev afgørende for udviklingen af ideen om individualitet, personlighed og identitet. Bykulturen blev ledsaget af fastlæggelsen af større magtenheder, der kulminerede med absolutismen i 1600-tallet og ideen om europæiske nationer (som dog i lande som Italien og Tyskland først fuldbyrdedes i løbet af 1800-tallet). Med kolonialismen fra det sene 1400tal og frem øgedes også bevidstheden om andre verdensdele og fremmede kulturer. Da først udviklingen af bogtryk og grafisk billedreproduktion tog fart, blev fremmede billedtraditioner - enten fra en fjern fortid eller fra fjerne egne - for alvor tilgængelige overalt og muliggjorde billedlån og -inspiration på tværs af geografiske og tidsmæssige afstande.

\section{FORNYELSER: FORHOLDET MELLEM KUNST OG NATUR}

De nye strømninger, der begyndte at manifestere sig omkring 1200, og som man kan hævde udviklede sig til det moderne igennem de efterfølgende århundreder, hænger sammen med fremvoksende byer som kulturelle centre. 1500-tallet kan her ses som overgangen fra traditionen fra antikken og middelalderen, hvor det gamle kolliderede eller syntetiseredes med de nye tendenser, der blev til det moderne. Interessen for kunstnerens "personlighed" og "stil" begyndte at manifestere sig på et hidtil uset teoretisk velartikuleret og kunstnerisk mangfoldigt niveau. Selve stilbetegnelsen manierisme, afledt af det italienske maniera (manér eller stil), går tilbage til 1500-tallets kunstneriske selvbevidsthed (Shearman, Mannerism 15-49). Denne stilbevidsthed udvikledes sideløbende med en øget naturalisme. I freskoudsmykninger i 1300-1400-tallet blev det ornamentale rammeværk ofte koblet med menneskeansigter, i forlængelse af traditionen tilbage til antikken. Men med udviklingen af naturalismen blev der nu undertiden 
122 KULTUR \& KLASSE * $123 * 2017$

TOPOLOGI

tilføjet en portrætlighed i de rankeindrammede ansigter, som er ukendt tilbage i den græsk-romerske oldtids maske-ranker. I en del tilfælde har det endda ført til en identifikation af ansigterne som kunstnerselvportrætter (billede 7). Udvekslingen mellem naturalisme og opfindsomhed var i det hele taget afgørende i denne kunstneriske kompositionsform som middel til at opnå en kraftfuld effekt. 1500-tallets billedkunst er rig på maskemotiver, som fanger beskuerens blik ved grimasser og øjne, der fokuseret kigger i bestemte retninger (billede 8). Tvetydigheder - som masken er en arketype på - dyrkedes i det hele taget både visuelt og litterært i form af uudgrundelige motiver eller betydninger. Rent teknisk udvikledes malemåder, der muliggjorde changerende farver og sammenhængende, illusionistisk overbevisende kropsligheder. I tavle- og lærredsmaleriet var oliemalingen, som gradvis vandt frem i løbet af 1400-tallet, uovertruffen som middel til at skabe de atmosfæriske virkninger og flydende overgange, der betingede de nye udforskninger af illusionisme og den menneskelige perceptions muligheder og grænser. Oliemalingen afløste den ældre praksis med at male med tempera, en æggeemulsion, der gav tørre, pigmentstærke farver, der vanskeligt lod sig blande med andre, og hvor lys og skygge blot bestod i pigmentintensitet (Shearman, "Leonardo's Color" 408-440). Nyt hen mod 1500, måske mest berømt med en maler som Leonardo da Vinci, var en udvikling af fremstillingen af lys og skygge ved hjælp af hvide og sorte farver, gradueret i den manipulerbare olie (Nagel; Vasari vol. Testo IV, 3-13). Men også i fresko (rumudsmykninger malet direkte på den våde puds) udvikledes malemåden, så den eftertragtede diffuse kropsgengivelse kunne opnås, med en overbevisende illusionisme og livagtighed i figur- og rumgengivelsen som konsekvens. Illusionismen muliggjorde en eftertragtet overraskelseseffekt: Er der tale om et skulpturelt relief eller blot om to-dimensionalt maleri? Og bevæger figuren sig og er levende, eller er det blot kunst?

Ligesom figurens tvetydighed og tilsynekomst f.eks. blev udforsket i den nye mode, som kunstige grotter udgjorde i fornemme haver (billede 9), blev fremtrædelsens metamorfose også værdsat i maleri. En pragthjelm, som den er skitseret af Francesco Salviati (1540'erne), er samtidig en monstrøs tilsynekomst (billede 10), en form for maske eller mystisk væsen, der kommer til live for øjnene af os. Og Arcimboldos malerier, der 
123 MARIA FABRICIUS HANSEN

MOTIVSTUDIER

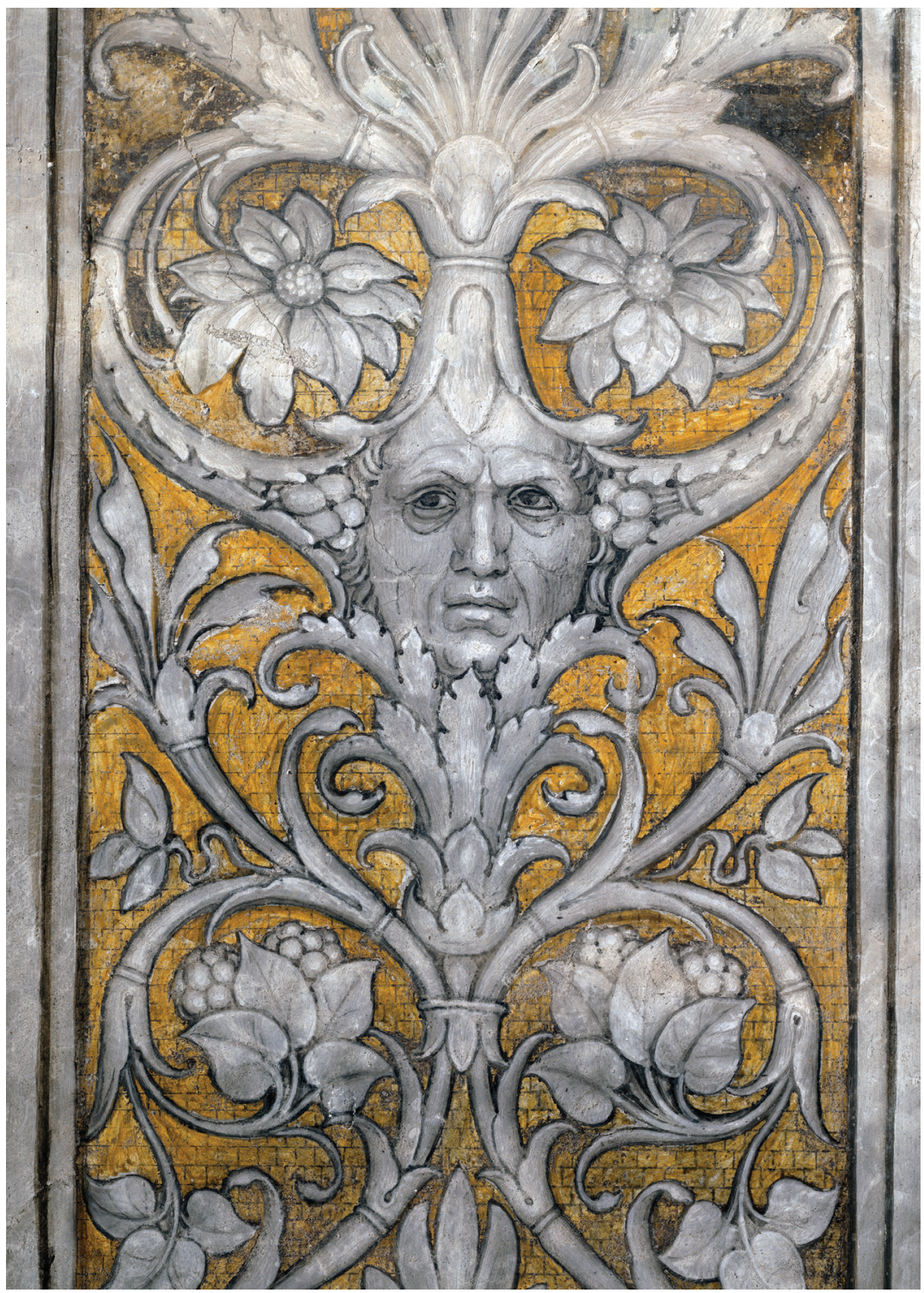

Fig. 7. Andrea Mantegna. Selvportræt i rankeværk på malet pilaster. Udsnit affreskoudsmykning, Det malede Værelse, Hertugpaladset i Mantova, ca. 1470. (C) 2016. Photo Scala, Florence - courtesy of the Ministero Beni e Att. Culturali. 
124 KULTUR \& KLASSE *123*2017 TOPOLOGI

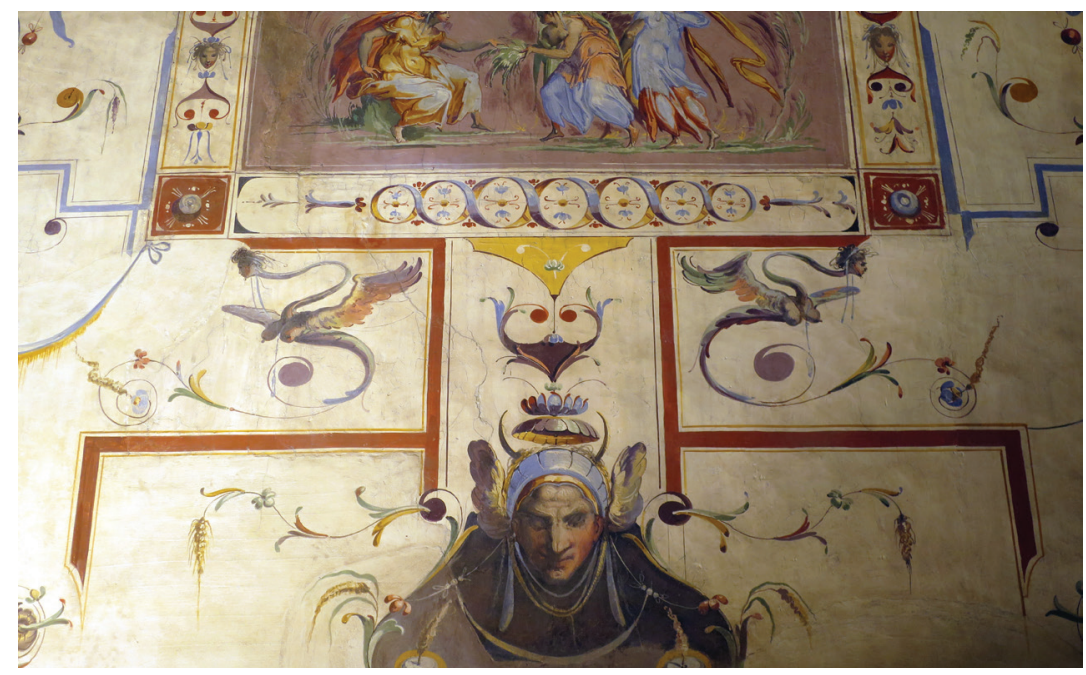

Fig. 8. Marco da Faenza og Giorgio Vasaris værksted, udsnit af freskoudsmykning med grotesker, Palazzo Vecchio, Firenze, midten af 1500-tallet. Foto: Maria Fabricius Hansen

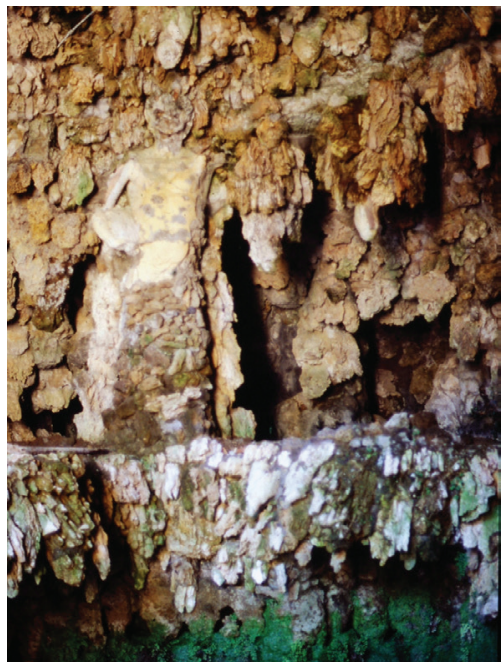

Fig. 9. Kunstig grotte med figur, der synes at komme til syne i klippevæggen som dannet af naturen. Villa Farnese, Caprarola, midten af 1500-tallet.

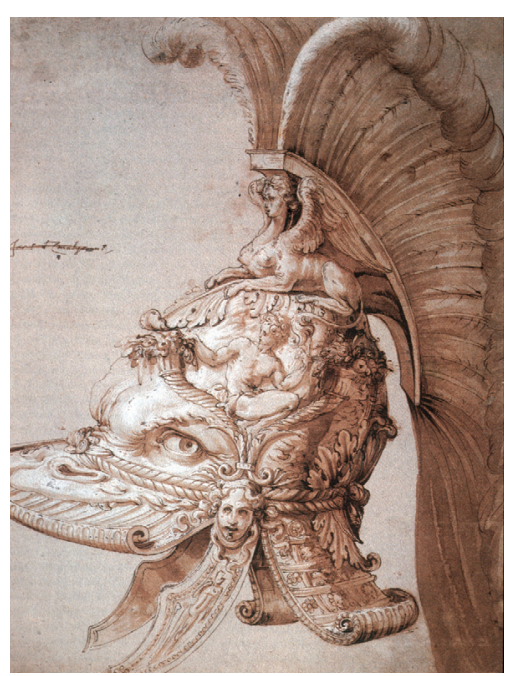

Fig. 10. Francesco Salviati, tegning af hjælm, 1541-43. Musée du Louvre, Department des Art Graphiques, Inventaire 6126, Paris. 


\section{MARIA FABRICIUS HANSEN MOTIVSTUDIER}

både kan fremstå som et portræt af et menneske og en præcis gengivelse af naturens bestanddele så som grøntsager, rummer en tilsvarende tidstypisk dobbelthed og glæde ved det paradoksale (Colie). Et af Arcimboldos billeder (ca. 1590) er paradoksalt i den forstand, at der er en "omvending" af betydninger: Set på den ene led er det et portræt, mens det på den anden led er en entydig naturalistisk gengivelse af en skål med rodfrugter (billede 11).

Som en altomfattende mode i 1500-tallets freskoudsmykninger af villaer og paladser er groteskerne et hovedeksempel på disse tendenser. Opmærksomheden på forholdet mellem tradition og fornyelse tydeliggør, at groteskemaleriets kombination af figur- og rankeværk i opfindsomme ornamentale forløb er noget andet end den antikgenoplivning, som groteskerne vedvarende forklares som inden for kunsthistorien (billede 12). Groteskemaleriets gængse kobling til antikken hænger sammen med den udforskning af den romerske kejser Neros Gyldne Hus (1. årh. e.v.t.), som kunstnere og andre interesserede begav sig ud i henimod slutningen af 1400-tallet (Dacos). De antikke ruiners underjordiske karakter førte til deres benævnelse som grotter, og deraf blev det dekorative vægmaleris grotesker afledt. Men det bemærkelsesværdige er, at 1500-tallets grotesker adskiller sig så markant fra de antikke forlæg på trods af datidens angivelige ønske om at imitere antikken. Det er netop den øgede kvalitet af hybriditet og metamorfose, der gør sig gældende også her, ligesom koblingen af stærk naturalisme i enkeltelementer gik hånd i hånd med en udpræget kunstfærdighed og opdyrkelse af kunstnerisk opfindsomhed i sammenstillingen af enkeltdelene (billede 12-13).

1500-tallet kan ses som den periode, hvor den antikke-middelalderlige tradition brydes med det, der bliver det moderne. Der finder et begyndende opgør sted med den gamle forestilling om naturen som en skabende kraft. At naturens bestanddele rummede et kreativt potentiale, og at figurens tilsynekomst allerede var antydet af naturen i materialet, inden kunstneren gik i gang med sin bearbejdning, blev udfordret af en ny opmærksomhed på billedets tilblivelse i kunstnerens fantasi og i beskuerens oplevelse. Pointen i 1500-tallets kunstige grotter var eksempelvis ikke, at beskueren skulle tro, at der var tale om et naturdannet rum; de blev derimod netop værdsat for deres kunstighed. 
126 KULTUR \& KLASSE * $123 * 2017$

TOPOLOGI
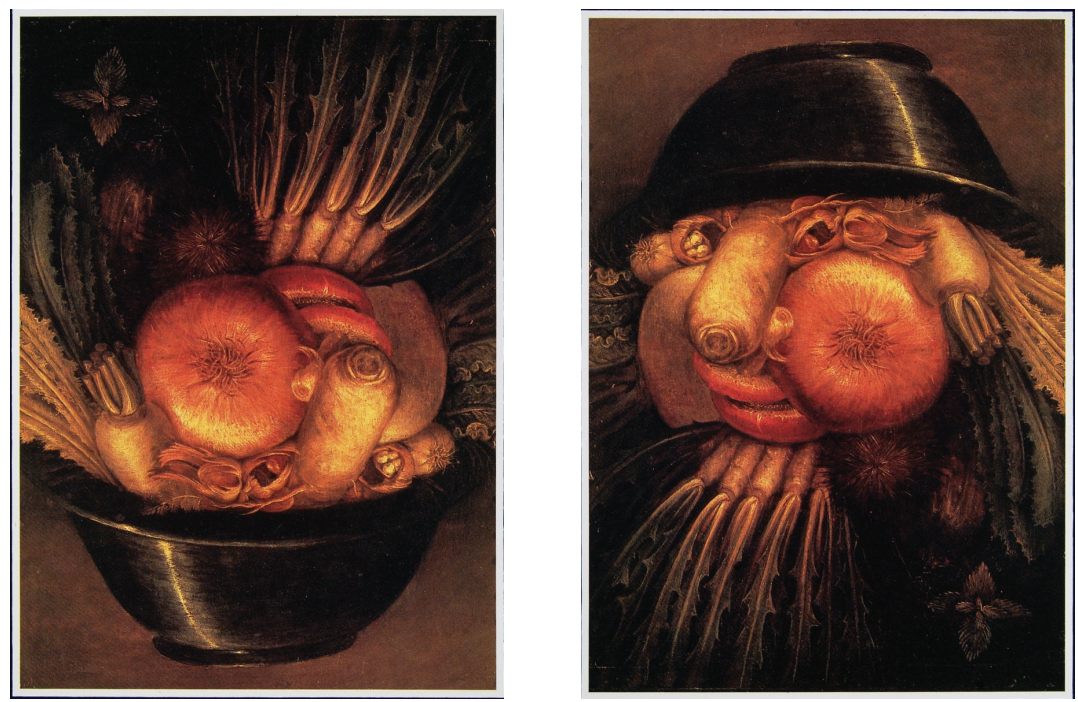

Fig. 11. Giuseppe Arcimboldo, vendbart maleri med hhv. "Stilleben" og "Gartneren", ca. 1590. Cremona: Museo Civico ala Ponzone. Foto: Wikimedia Commons

I 1600-tallet blev ideen om, at kunstnerens virksomhed var et produktivt samarbejde med naturen, erstattet af et nyt ideal om menneskets beherskelse af eller kontrol med naturen. Her afløstes 1500-tallets til tider ekstreme kunstighed og komplekse afkodningsideal også af en demonstrativ naturalisme eller virkelighedseffekt, som er væsentlige aspekter af 1600-tallets systematiserende, regelmenterede, hierarkiserende kunst (Bredekamp).

Den ny naturopfattelse, der var undervejs, blev formet af (og formede) 1500-tallets tilbøjelighed til empiriske studier, stærkt understøttet af den trykte bog og den mekaniske billedreproduktions lærdomsakkumulation. Frem til 1500-tallet tænkte man helt overvejende i ligheder og overfladiske sammenhænge (en mand, der ligner en løve, er også en modig mand; en mand, der ligner et æsel, er dum og stædig; en valnød, der ligner en hjerne, hjælper på hovedpine) (Della Porta; Foucault; Freedberg). Med 150o-tallet opstod et ønske om at nå ind under eller bag om den synlige overflade. Det gjorde sig gældende i både kunstnerisk og videnskabelig praksis, f.eks. i de nye dissektionsstudier, som var led i den ligeledes nye institution, 

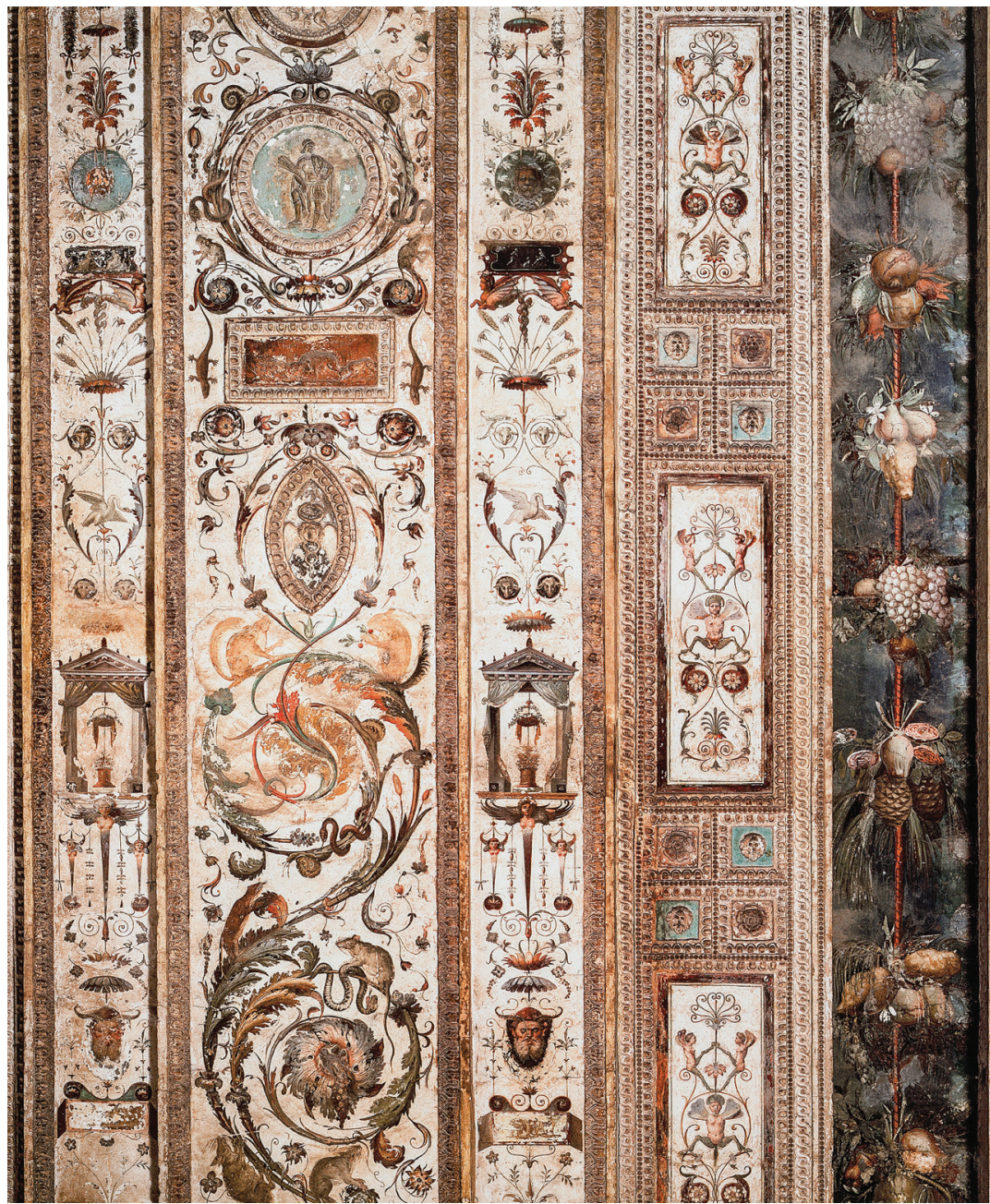

Fig. 12. Giovanni da Udine og Rafaels værksted, Loggia, ca. 1519. Vatikanet. Foto: A. Zamperini. Le Grottesche: Il sogno della pittura nella decorazione parietale. Verona: Arsenale, 2007, 129 
128 KULTUR \& KLASSE * $123 * 2017$ TOPOLOGI

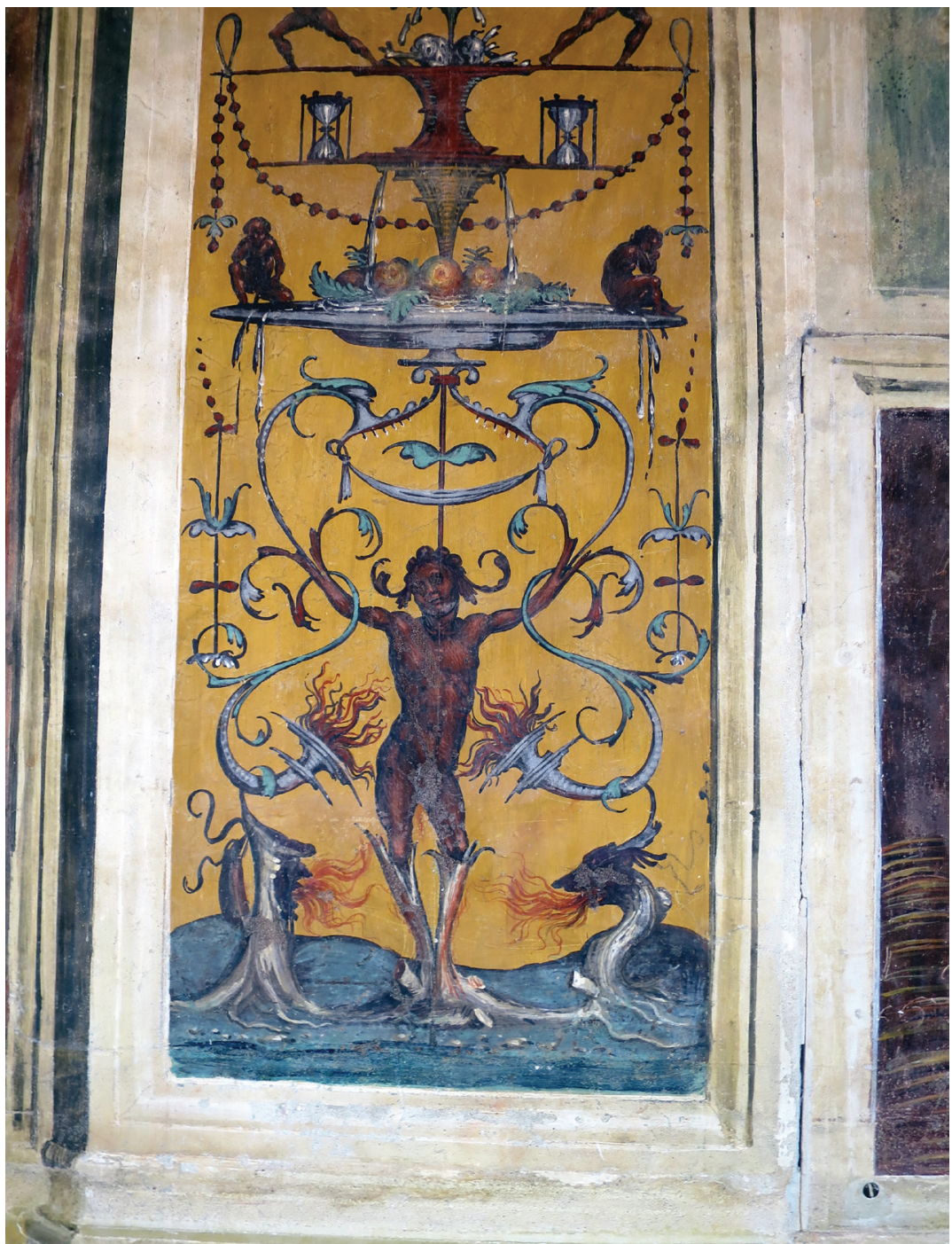

Fig. 13. Sodoma, Udsnit af malet pilaster med grotesker, Abbazia di Monteoliveto Maggiore, ca.1500. Foto: Maria Fabricius Hansen 


\section{MARIA FABRICIUS HANSEN MOTIVSTUDIER}

kunstakademiets curriculum (Accademia del Disegno, grundlagt af Vasari i Firenze, 1563) (Jacobs 426-448). Og det gjorde sig gældende i udviklingen af nye synsteknologier (teleskoper, mikroskoper), der muliggjorde studiet af hidtil usynlige verdener.

Den dyrkelse af metamorfosens tvetydighed, der begyndte at opstå omkring 1200-tallet, og som i 1500-tallet blev suppleret med en markant kunstighed eller kunstfærdighed, måske endda en ironisk distance, kan ses som konsekvensen af en veludviklet bykultur, hvor distancen til naturen og landbruget blev øget hos den kulturelle elite. 1500-tallets bykultur var en mulighedsbetingelse for en naturalistisk planteornamentik, men samtidig også grundlaget for en ny perceptionsrelativisme: en bevidsthed om, at ting ser forskellige ud set fra forskellige sider og under forskellige omstændigheder. Denne erkendelse, som hang sammen med en forståelse af mennesker som individer med forskellig personlighed, var ledsaget af en foruroligelse over, men også glæde ved foranderlighed, forvandling, tvetydighed. Alt i alt en optagethed af bevægelse, som blev et kendetegn ved det moderne.

Motivstudierne kan således vise, at der er tale om en vedvarende tradition for ornamental billedkunst, herunder rankeværk med figurer, fra antikken og frem igennem middelalderen. Derved kan man modificere den kunsthistoriske fagtraditions tilbøjelighed til at stille sig tilfreds med en forklaring af renæssancens kunst som en genoplivning af antikken. Og samtidig kan motivstudierne bidrage til at belyse, hvad der adskiller 1500-tallets billedkunst, eksempelvis groteskerne, fra den ældre tradition.

Den form for kontinuitet og fornyelse, som en oversigt af denne art kan fremskrive, er baseret på en forestilling om, at billedverdener og verdensbilleder hænger sammen. Som vi har set, er Wölfflins iagttagelse - at ikke alt er muligt til alle tider - en grundlæggende forudsætning for en sådan forståelse af kunsthistoriske sammenhænge. En inddragelse af de samfundsmæssige forandringer, der finder sted igennem århundrederne, kan være én måde at forklare de skiftende billedverdener på. Forklaringerne på deres ligheder og forskelle må imidlertid forblive tentative og vil næppe på nogen meningsfuld måde kunne bringes til en definitiv konklusion. Der synes at være tale om komplicerede, reciprokke virkninger mellem mennesker, billeder og omverden, snarere end om processer, der kan kortlægges entydigt. Et formål med motivstudierne vil således først og fremmest være 
130 KULTUR \& KLASSE *123*2017

TOPOLOGI

at pege på mønstre, mulige sammenhænge og markante nybrud over tid; men de fortolkninger eller forklaringer, de afstedkommer, vil kunne antage en mangfoldighed af former.

Maria Fabricius Hansen er dr.phil. og lektor i kunsthistorie ved Institut for Kunst- og Kulturvidenskab, Københavns Universitet. Hendes aktuelle forskning omhandler det 16. århundredes italienske kunst og arkitektur, men hun beskæftiger sig i sin forskning og undervisning også med samtidskunst og -arkitektur.

\section{TRACING MOTIFS}

Continuity and Innovation in Hybrid Ornaments from Antiquity to c. 1600

Representations of hybrids of human figures, plants, and animals were prolific in all media in sixteenth-century Italian art. The motif is known back from Greek and Roman antiquity, both in poetry and visual art, which the artists of the sixteenth century - or the renaissance - claimed to revive. Yet the representations of hybrids from these two periods within the history of art differ remarkably. And at the same time they belong to an iconographic tradition that did not disappear in the medieval period, an observation which blurs the picture of these ornaments as rediscovered and revived in the renaissance.

How then do motifs such as foliate heads or other phyto- or zoomorph creatures develop in visual art from antiquity to ca. 1600 ?

The topological method can be applied to a tracking of these motifs over time in order to stress continuity and analyze the transformations which took place through the centuries.

This article reflects on some methodological and historiographical aspects of studies of motifs in art history. In a double-sided strategy it both aims at challenging the persistent notion of the renaissance as a period rejecting the middle ages and reviving antiquity (i.e. it stresses the continuity of the sixteenth century with the preceding centuries); and it suggest some characteristics of the visual paradigm of sixteenth-century Italian art (i.e. it describes some of the innovations of the period). 


\section{MARIA FABRICIUS HANSEN MOTIVSTUDIER}

\section{KEYWORDS}

DA: kunsthistorie, billedkunst, grotesker, kontinuitet, transformation

EN: art history, painting, grotesques, continuity, transformation

\section{LITTERATUR}

Aristotle. Physics. Overs. F.M. Cornford. Cambridge, Massachusetts \& London: Harvard University Press, 1957.

Baltrusaitis, Jurgis. Le Moyen Age Fantastique: Antiquitès et exotismes dans l'art gothique. Paris: Armand Colin, 1955.

Bernard de Clairvaux, i red. Caecilia Davis-Weyer. Early Medieval Art 300-1150: Sources and Documents. Toronto: University of Toronto Press, 1986. 168-170.

Bredekamp, Horst. Antikensehnsucht und Maschinenglaube: Die Geschichte der Kunstkammer und die Zukunft der Kunstgeschichte. Berlin: Klaus Wagenbach, (1993) 2002.

Brown, Peter. The Body and Society: Men, Women, and Sexual Renunciation in Early Christianity. New York: Columbia University Press, 1988.

Bynum, Caroline Walker. Metamorphosis and Identity. New York: Zone Books 2005.

Cennini, Cennino. Bogen om malerkunsten. Overs. Hannemarie Ragn Jensen. København: Nyt Nordisk Forlag Arnold Busck, 1996.

Colie, Rosalie L. Paradoxia Epidemica: The Renaissance Tradition of Paradox. Princeton, New Jersey: Princeton University Press, 1966.

Curtius, Ernst Robert. European Literature and the Latin Middle Ages. Overs. Willard R. Trask, Bollingen Series XXXVI. Princeton, New Jersey: Princeton University Press, (1953) 2013.

Curtius, Ludwig. "Die Rankengöttin: Ein Vortrag" (1951). Torso: Verstreute und Nachgelassene Schriften. Red. Joachim Moras. Stuttgart: Deutsche Verlags-Anstalt, 1957. 192-210.

Dacos, Nicole. La Découverte de la Domus Aurea et la formation des grotesques a la renaissance. London: The Warburg Institute, 1969.

Della Porta, Giambattista. De humana physiognomonia l libri IIII. Vici Aequensis: 1586.

Didi-Huberman, Georges. Atlas ou le gai savoir inquiet (L'Oeil de l'histoire, 3). Les Éditions de Minuit: Lonrai, 2011.

Didi-Huberman, Georges. "Nachleben, ou l'anthropologie du temps: Warburg avec Tylor" og "Renaissance et impureté du temps: Warburg avec Burckhardt". L'Image Survivante: Histoire de l'Art et Temps des Fantômes selon Aby Warburg. Les Éditions de Minuit: Lonrai 2002. 51-60 og 71-81.

Elsner, Jas. Imperial Rome and Christian Triumph: The Art of the Roman Empire A.D. 100-450. (Oxford History of Art). Oxford: Oxford University Press, 1998.

Elsner, Jas. Art and the Roman Viewer: The Transformation of Art from the Pagan World to Christianity. Cambridge, New York \& Melbourne: Cambridge University Press, 1995.

Focillon, Henri. The Life of Forms in Art. Overs. Charles Beecher Hogan \& George Kubler. New York: Wittenborn, Schultz (1934) 1948. 


\section{KULTUR \& KLASSE * $123 * 2017$}

TOPOLOGI

Foucault, Michel. Ordene og tingene: En arkæologisk undersøgelse af videnskaberne om mennesket. Overs. Chr. Svendsen. Spektrum, Viborg, (1966) 1999.

Freedberg, David. The Eye of the Lynx: Galileo, his friends, and the beginnings of modern natural history. Chicago and London: The University of Chicago Press, 2002.

Gombrich, Ernst H. The Sense of Order: A Study in the Psychology of Decorative Art. London: Phaidon, 1979.

Horats, Horace. Ars Poetica, i Horace: Satires, Epistles and Ars Poetica. Overs. H. Rushton Fairclough. Cambridge, Mass. \& London: Harvard University Press, 1970.

Jacobs, Fredrika. "(Dis)assembling. Marsyas, Michelangelo, and the Accademia del Disegno". Art Bulletin, 863 (2002): 426-448.

Janson, H.W. "The Image Made by Chance in Renaissance Thought". De artibus opuscula XL: Essays in Honor of Erwin Panofsky. Red. M. Meiss. New York: New York University Press, 1961. 254-266.

Johnson, Christopher D. Memory, Metaphor, and Aby Warburg's Atlas of Images. Ithaca, New York: Cornell University Press \& Cornell University Library, 2012.

Nagel, Alexander. "Leonardo and Sfumato."Res 24, autumn (1993): 7-20.

Nagel, Alexander \& Christopher S. Wood. Anachronic Renaissance. New York: Zone Books, 2010.

Panofsky, Erwin. Die Perspektive als symbolische Form: Vorträge der Bibliothek Warburg 1924-1925. Leipzig \& Berlin: Teubner, 1927.

Panofsky, Erwin. Renaissance and Renascences in Western Art. Stockholm: Almqvist \& Wiksell, 1960.

Pictor in Carmine. Ein Handbuch der Typologie aus der Zeit um 1200. Nach MS 300 des Corpus Christi College in Cambridge. Red. Karl-August Wirth. Berlin: Gebr. Mann Verlag, 2006.

Plinius den Ældre: Pliny. Natural History. Overs. H. Rackham \& D.E. Eichholz. Cambridge, Massachusetts \& London: Harvard University Press, 1952-62.

Riegl, Alois. Problems of Style: Foundations for a History of Ornament. Overs. Evelyn Kain, noter, ordforklaring og introduction David Castriota, forord Henri Zerner. Princeton: Princeton University Press, 1992.

Riegl, Alois. Die spätrömische Kunstindustrie. Wien: Verlag der Österreichische Statsdruckerei (1901) 1927.

Rupp, Wayne L. Jr. "The Vegetal Goddess in the Tomb of Typhon." Etruscan Studies: Journal of the Etruscan Foundation. 10 (2007): 211-219.

Schauenburg, Konrad. "Zur Symbolik unteritalienischen Rankenmotive," Mitteilungen des deutschen archaeologischen Instituts Roemische Abteilung. 64 (1957): 198-221.

Shearman, John. "Leonardo's Color and Chiaroscuro." Sixteenth-Century Italian Art. Red. Michael W. Cole. Oxford: Blackwell Publishing, 2006. 408-440.

Shearman, John. Mannerism. London \& Harmondsworth: Penguin (1967) 1990.

Toynbee, J.M.C. \& J.B. Ward Perkins. "Peopled Scrolls: A Hellenistic Motif in Imperial Art." Papers of the British School at Rome. 18 (1950): 1-43.

Vasari, Giorgio. Le Vite de' Più eccellenti pittori scultori e architettori nelle redazioni del 1550 e 1568. Red. R. Bettarini \& P. Barocchi. Firenze: Sansoni, 1966-1997. 


\section{MARIA FABRICIUS HANSEN MOTIVSTUDIER}

Vitruvius. Ten Books on Architecture. Overs. Ingrid D. Rowland, komment. Thomas Noble Howe. New York: Cambridge University Press, 1999.

Wamberg, Jacob. Landscape as World Picture: Tracing Cultural Evolution in Images (vol. 1-2). Aarhus: Aarhus University Press, 2009.

Weiss, Roberto. The Renaissance Discovery of Classical Antiquity, Oxford: Blackwell, 1969. Wölfflin, Heinrich. Die Klassische Kunst: Eine Einführung in die italienische Renaissance. Basel \& Stuttgart: Schwabe \& Co., (1898 ) 9. udg. 1968.

Wölfflin, Heinrich. Kunstgeschichtliche Grundbegriffe: Das Problem der Stilentwicklung in der neueren Kunst. München: F. Bruckmann, 1915. 
134 KULTUR \& KLASSE * $123 * 2017$ TOPOLOGI 